\title{
Quantitative Analysis and Preformulation of Extracts from Alnus Japonica
}

\author{
Jong-Suep Baek*, Hee-Chul Kang*, Chang-Gu Keum, Ji-Ho Lim, Chan-Ju Hwang, \\ Young-Guk Na, N.H. Tung, Young-Ho Kim and Cheong-Weon Cho ${ }^{\dagger}$ \\ College of Pharmacy and Institute of Drug Research and Development, Chungnam National University, \\ 220 Gungdong, Yuseonggu, Daejeon 305-764, South Korea \\ (Received May 9, $2011 \cdot$ Revised June 11, $2011 \cdot$ Accepted July 1, 2011)
}

\begin{abstract}
Alnus japonica has been known to exert antioxidative, anti-inflammatory, anti-cancer and immune response inhibitory effects. The aim of this study was to figure out the characteristics of extracts obtained with different extraction solvent such as water, $100 \%$ ethanol, $70 \%$ ethanol or $70 \%$ methanol because characteristic components such as oregonin and hirsutanone extracted from Alnus japonica might be essential for the biological activity. For this purpose, oregonin and hirsutanon of four extracts, index ingredient of Alnus japonica, were analyzed with HPLC and physicochemical studies such as SEM, particle size and zeta potential were conducted. In cell cytotoxicity study, extract of water showed the highest cytotoxicity among four extracts. In case of oregonin, $70 \% \mathrm{MeOH}$ and water extracts showed high contents and in case of hirsutanone, all extracts showed similar contents except $70 \% \mathrm{EtOH}$ extracts. The extract of $70 \% \mathrm{MeOH}$ from Alnus japonica for both oregonin and hirsutanone appeared to have the highest content. Both oregonin and hirsutanone extracted from Alnus japonica using $70 \%$ methanol showed stability in $\mathrm{pH} 1.2$.
\end{abstract}

Key words - Alnus japonica, Extracts, Oregonin, Hirsutanone, pH stability, Cytotoxicity, Preformulation

The bark of Alnus japonica has been used for fever, hemorrhage, gastroenteric disorder, lymphatic disease and cancers in oriental traditional medicine (Lee, 1996). It was reported that two diarylheptanoids, hirsutanone and oregonin isolated from Alnus japonica showed a potent antioxidant activity (Kehrer et al., 1993). Briefly, hirsutanone was shown to inhibit the TPA-induced upregulation of cyclooxygenase-2 and matrix metalloproteinase-9 through suppression of NF-kB transcriptional activity in human mammary epithelial cells (Kim et al., 2006). Also, it was shown to exert antioxidative activity (Masanori et al., 2005), nitric oxide synthase inhibitory activity (Choi et al., 2009), inhibitory activity of cyclooxygenase-2 expression (Lee et al., 2000), inhibitory activity of melanogenesis (Cho et al., 2002) and anti-inflammatory effects (Kang et al., 2004). On the other hand, it was known that oregonin exerted several anti-inflammatory activities (Lee et al., 2000; Lee et al., 2000; Kim et al., 2005) and anti-apoptotic properties in vitro, which were inhibitory effect on the production of cytokine, the formation of reactive oxygen species and nitric oxide as well as the change in intracellular $\mathrm{Ca}^{2+}$ levels in dendritic cells of bone marrow and spleen exposed to microbial products and IL-1B (Choi et al., 2008). Therefore, the amount of hirsu-

\footnotetext{
*These authors are equally contributed to this work

${ }^{\dagger}$ Corresponding Author:

Tel : +82-42-821-5934, E-mail : chocw@cnu.ac.kr

DOI : 10.4333/KPS.2011.41.4.227
}

tanone and oregonin extracted from Alnus japonica might be important for biological activity.

In this study, four different extracts obtained from Alnus japonica according to various extraction solvent were prepared and the contents of two hirsutanone and oregonin were determined. As well as, the physicochemical properties of four different extracts were characterized with scanning electron microscopy (SEM), particle size measurement, and then, cytotoxicity study of four different extracts against Caco-2 cells was carried out. This study was carried out to figure out the physicochemical characteristics of Alnus japonica extracts because those are very important for development as herbal medicines.

\section{Materials and Methods}

\section{Materials}

Ethanol (EtOH), methanol $(\mathrm{MeOH})$ and acetonitrile were purchased from J.T.Baker (St Louis, USA). MTT kit was purchased from Sigma (Steinheim, Switzerland). Distilled water was filtered with Mill Q (Milford, MA, USA). All other chemicals and solvents were of analytical reagent grade and used without further purification.

\section{Preparation of extracts from Alnus japonica}

Air-dried $50 \mathrm{~g}$ of barks of Alnus japonica were extracted with $100 \mathrm{~mL}$ of $100 \%$ ethanol, $70 \%$ ethanol, $70 \%$ methanol or 
water by three times at $40^{\circ} \mathrm{C}$ for $8 \mathrm{hr}$ under ultrasound-assistance, respectively. Then the obtained extracts were filtered through Whatman No. 2 filter paper and exhaustively concentrated in vacuo to dryness.

\section{Cell cultures}

Caco-2 cells were purchased from the Korean cell line bank (Seoul, Korea). Caco-2 cells (passage number 46-52) were cultured in DMEM supplemented with $10 \%$ FBS, 1\% NEAA, 100 units $/ \mathrm{mL}$ penicillin and $0.1 \mathrm{mg} / \mathrm{mL}$ streptomycin in a $5 \%$ $\mathrm{CO}_{2}$ atmosphere with $95 \%$ humidity in a $37^{\circ} \mathrm{C}$ incubator.

HPLC condition of characteristic components, oregonin and hirustanone

Oregonin and hirustanone were dispersed in $80 \% \mathrm{MeOH}$ and the standard solutions according to the concentrations from 0.05 to $500 \mu \mathrm{g} / \mathrm{mL}$ for oregonin and 0.02 to $200 \mu \mathrm{g} / \mathrm{mL}$ for hirustanone were prepared, respectively. These samples were filtered through a $0.45 \mu \mathrm{m}$ filter. The filtrates were analyzed by HPLC. Four mg of four different extracts obtained from Alnus japonica were dispersed in $1 \mathrm{~mL}$ of each extraction solution. The HPLC system was consisted of a Capcell pak C18 column $(150 \times 4.6 \mathrm{~mm}, 5 \mu \mathrm{m}$; MG120, Shiseido, Tokyo, Japan) thermostated at room temperature. UV absorption was measured at $280 \mathrm{~nm}$. The mobile phase was consisted of water (A) and acetonitrile (B), respectively. The flow rate was $1 \mathrm{~mL} /$ min and the elution gradient was as follows: $0 \mathrm{~min}$, A of $90 \%$; $0-12 \min$, A of $75 \% ; 12-24 \mathrm{~min}$, A of $60 \%$.

Determination of the surface area of four different extracts obtained from Alnus japonica

The surface area of four different extracts obtained from Alnus japonica was examined by surface area and porosimetry analyzer (ASAP 2010, Micromeritics, Norcross-GA, USA). The four different extracts obtained from Alnus japonica were melted at $60^{\circ} \mathrm{C}$ and their surface area was determined using a BET method (Carstensen et al, 2001).

Measurements of particle size and zeta potential of four different extracts obtained from Alnus japonica

The particle size and zeta potential analysis of four different extracts obtained from Alnus japonica were performed by laser scattering analyzer (ELS-8000, Otasuka Electronics, Osaka, Japan). The extracts were dispersed in water, added to the sample dispersion unit and then sonificated in order to minimize the inter-particle interactions. The obscuration range was maintained between $20-50 \%$. The instrument was set to measure the sample 50 times and the average volume mean diameter was obtained.
Observation of surface morphology of four different extracts of four different extracts obtained from Alnus japonica

The morphology and surface characteristics of four different extracts of four different extracts obtained from Alnus japonica were examined by scanning electron microscopy (SEM) (JEOL JSM7500, Thermo, Tokyo, Japan). The samples were mounted onto metal stubs using double-sided adhesive tape onto which the samples were applied. The stubs were sputtercoated with gold particles in a sputter coater for $2 \mathrm{~min}$.

\section{Cytotoxicity study of four different extracts obtained from Alnus japonica}

The in vitro anti-proliferation activity was assayed on Caco2 cell line. Cytotoxicity of four different extracts obtained from Alnus japonica was evaluated by MTT method. The experiment was carried out as follows: $100 \mu \mathrm{L}$ cell culture medium containing $5 \times 10^{4}$ cells, were added in each well in a 96-well plate and incubated for $24 \mathrm{hr}$. The confluent wells were treated with various concentrations of four different extracts. After $72 \mathrm{hr}$ of incubation, the plates were washed with PBS; $100 \mu \mathrm{L}$ of culture medium containing $20 \mu \mathrm{L}$ of MTT was added to the plate and incubated for a further $3 \mathrm{hr}$. After this, the contents of the plates were replaced with $100 \mu \mathrm{L}$ of solubilization solution and optical density at $570 \mathrm{~nm}$ was measured.

\section{pH stability studies of $\mathbf{7 0} \%$ methanol extract obtained from Alnus japonica}

An excess amount of $70 \%$ methanol extract obtained from Alnus japonica was added to $\mathrm{pH} 1.2$ or $\mathrm{pH} 6.8$ solutions and shaken for $48 \mathrm{hr}$ at $25^{\circ} \mathrm{C}$. The mixture was centrifuged at $8000 \times g$ for $20 \mathrm{~min}$ (Hamada, Ishiara, Masuoka, Mikuni, \& Nakajima, 2006), and the supernatant was passed through a $0.45 \mu \mathrm{m}$ filter. The drug concentration in filtrate was determined by HPLC.

\section{Results and discussion}

Assay of characteristic components, oregonin and hirustanone

Alnus japonica has been known to exert antioxidative, antiinflammatory, anti-cancer and immune response inhibitory effects due to the characteristic components such as oregonin and hirsutanone, so the amount of oregonin and hirsutanone extracted from Alnus japonica might be essential for the biological activity. Therefore, the aim of this study was to figure out the physicochemical characteristics of extracts obtained from Alnus japonica with various extraction solvents such as 
water, $100 \%$ ethanol, $70 \%$ ethanol or $70 \%$ methanol, respectively.

Calibration curves of hirsutanone and oregonin were constructed covering a concentration range from 0.05 to $500 \mu \mathrm{g} /$ $\mathrm{mL}$ for oregonin and 0.02 to $200 \mu \mathrm{g} / \mathrm{mL}$ for hirsutanone. In this condition, the correlation coefficiencies of calibration curves were 1 , respectively. The limit of quantification was $0.05 \mu \mathrm{g} / \mathrm{mL}$ for oregonin and $0.02 \mu \mathrm{g} / \mathrm{mL}$ for hirsutanone. The retention time was $4.0 \mathrm{~min}$ for oregonin and $7.0 \mathrm{~min}$ for hirsutanone, respectively. The chromatogram of each characteristic component, oregonin and hirsutanone was clearly separated. Four different extracts obtained from Alnus japonica with water, $70 \% \mathrm{EtOH}, 70 \% \mathrm{MeOH}$ or $100 \% \mathrm{EtOH}$ were dissolved in water, $70 \% \mathrm{EtOH}, 70 \% \mathrm{MeOH}$ or $100 \% \mathrm{EtOH}$, respectively. The concentration of oregonin extracted from Alnus japonica with $100 \% \mathrm{EtOH}, 70 \% \mathrm{EtOH}, 70 \% \mathrm{MeOH}$ or water was $451.29 \pm 14.80,503.11 \pm 23.25,644.12 \pm 16.01$ or $610.02 \pm$ $10.34 \mu \mathrm{g} / \mathrm{mL}$, respectivley and that of hirsutanone extracted from Alnus japonica with 100\% EtOH, 70\% EtOH, 70\% $\mathrm{MeOH}$ or water was $17.75 \pm 3.69,14.81 \pm 5.80,18.41 \pm 3.99$ or $18.29 \pm 2.58 \mu \mathrm{g} / \mathrm{mL}$, respectively. Oregonin was more extracted than hirsutanone under the same extraction solvent. The

(A)

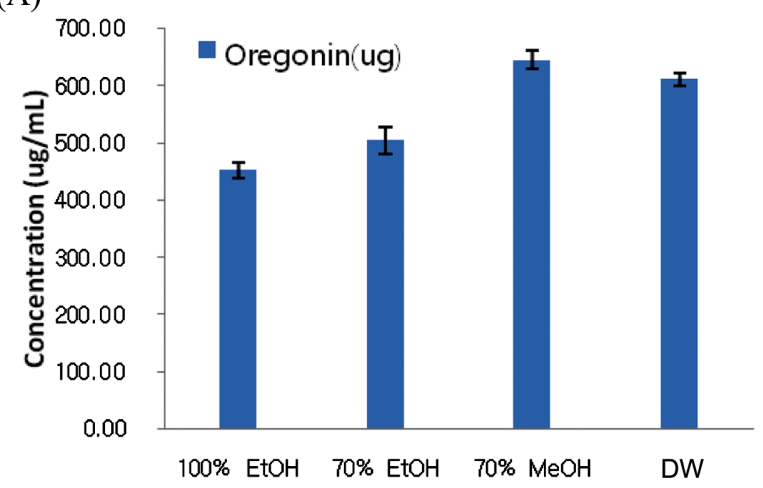

(B)

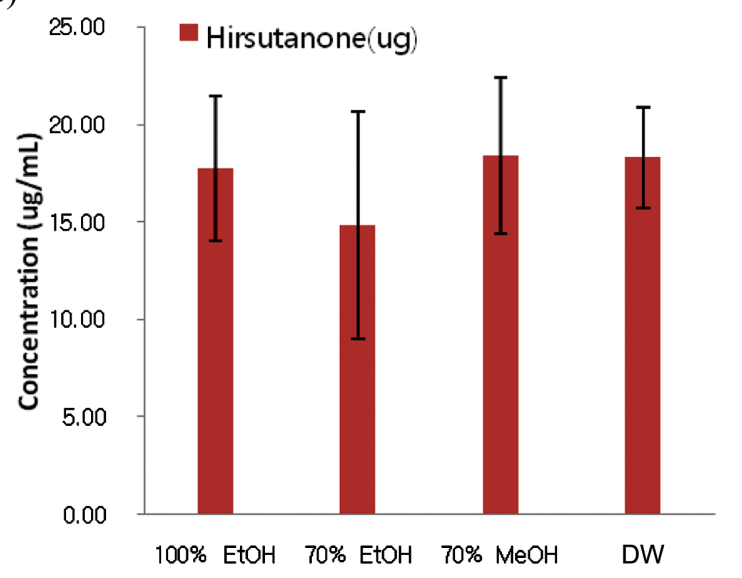

Figure 1. Concentration of oregonin (A) and hirsutanone (B) in four different extracts. seventy $\% \mathrm{MeOH}$ extracts showed the highest amounts of oregonin and hirsutanone among four different extracts obtained from Alnus japonica (Figure 1). It was understood that a methanol extract of the leaves of Alnus japonica was found to have strong antioxidative activity (Kuroyanagi et al., 2005). Through the results of the assay of characteristic components, oregonin and hirsutanone, the amount of extracted components could be variable, subsequently, leads to different biological activity. In future, the characterizations on the extracts might be essential to assure the quality of the extracts.

\section{Determination of surface area of four different extracts obtained from Alnus japonica}

The BET surface area of water extracts obtained from Alnus japonica was $0.69 \mathrm{~m}^{2} / \mathrm{g}$, that of $70 \% \mathrm{EtOH}$ extracts was 8.99 $\mathrm{m}^{2} / \mathrm{g}$, that of $100 \% \mathrm{EtOH}$ extracts was $0.96 \mathrm{~m}^{2} / \mathrm{g}$ and that of $70 \% \mathrm{MeOH}$ extracts was $1.32 \mathrm{~m}^{2} / \mathrm{g}$, respectively (Table I).

\section{Measurements of particle size and zeta potential analysis of four different extracts obtained from Alnus japonica}

We compared the physicochemical properties of four different extracts obtained from Alnus japonica according to various extraction solvent by measuring the particle size and surface charge by zeta potential (Table II). Water extracts obtained from Alnus japonica showed the smallest size, 595.6 $\mathrm{nm}$ among four different extracts and 100\% EtOH extracts showed the biggest size, $2234.3 \mathrm{~nm}$. Interestingly, water extracts from Alnus japonica showed a positive value of zeta potential but other extracts except for water extracts showed the negative value of zeta potential.

Table I. The surface area of four different extracts

\begin{tabular}{ccc}
\hline \hline $\begin{array}{c}\text { Extraction } \\
\text { solvent }\end{array}$ & $\begin{array}{c}\text { BET surface area } \\
\left(\mathrm{m}^{2} / \mathrm{g}\right)\end{array}$ & $\begin{array}{c}\text { Langmuir surface area } \\
\left(\mathrm{m}^{2} / \mathrm{g}\right)\end{array}$ \\
\hline $100 \% \mathrm{EtOH}$ & 0.9646 & 1.2239 \\
$70 \% \mathrm{EtOH}$ & 8.9848 & 11.4052 \\
$70 \% \mathrm{MeOH}$ & 1.3178 & 1.7390 \\
$\mathrm{DW}$ & 0.6904 & 0.8459 \\
\hline
\end{tabular}

Table II. Particle size and zeta potential of four different extracts

\begin{tabular}{ccc}
\hline \hline & Particle size $(\mathrm{nm})$ & Zeta potential $(\mathrm{mV})$ \\
\hline $100 \% \mathrm{EtOH}$ & $938.0 \pm 27.0$ & -0.71 \\
$70 \% \mathrm{EtOH}$ & $610.4 \pm 25.7$ & -3.66 \\
$70 \% \mathrm{MeOH}$ & $740.4 \pm 31.6$ & -1.34 \\
$\mathrm{DW}$ & $565.8 \pm 30.1$ & 1.56 \\
\hline
\end{tabular}


Observation of surface morphology of four different extracts obtained from Alnus japonica

The pictures of four different extracts obtained from Alnus japonica showed that the particles were generally of flat-type shape (Figure 2). Particles of extracts obtained from Alnus japonica with water were more uniform than that of other extract. In physicochemical property, the extracts obtained from Alnus japonica with water and $70 \% \mathrm{EtOH}$ extracts were smaller than other extracts. In case of the extracts obtained from Alnus japonica with water, the surface charge was positive compared to other extracts. There was no relationship between the particle size and the surface area of four different extracts. As the surface area of four different extracts was increased, the zeta potential value was negative.

\section{Cytotoxicity study of four different extracts obtained from Alnus japonica}

The cytotoxic effects of four different extracts obtained from Alnus japonica on the Caco-2 cells ranging from 10 to $600 \mu \mathrm{g} /$ $\mathrm{mL}$ were investigated using the MTT assay. The $100 \% \mathrm{EtOH}$, $70 \% \mathrm{EtOH}$ or $70 \% \mathrm{MeOH}$ extract showed the cell viability of $43.8 \pm 4.6 \%, 42.4 \pm 3.1$ or $36.1 \pm 1.4 \%$, respectively, but water extract exhibited the cell viability of $33.7 \pm 2.6 \%$ at $400 \mu \mathrm{g} / \mathrm{mL}$. Based on cytotoxicity results, water extract showed the most cytotoxic result among four different extracts (Figure 3). This result suggested that the extracts obtained from Alnus japonica
(A)

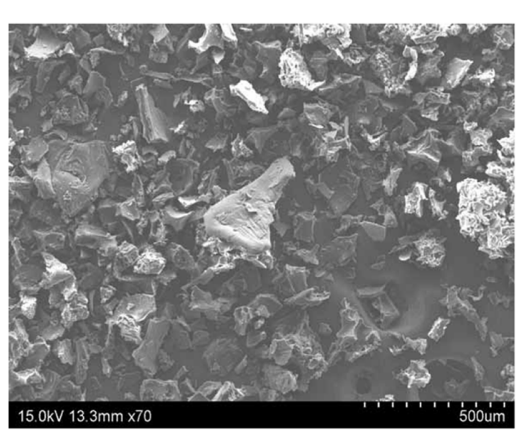

(C)

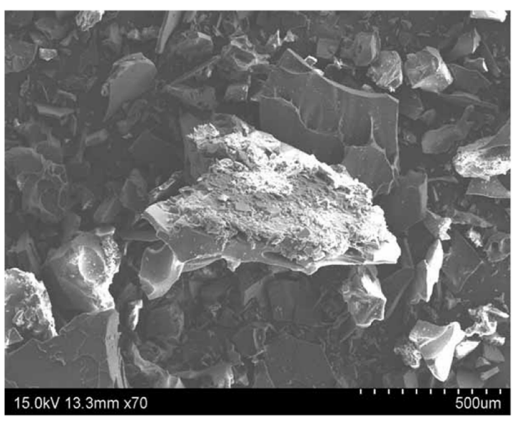

(B)

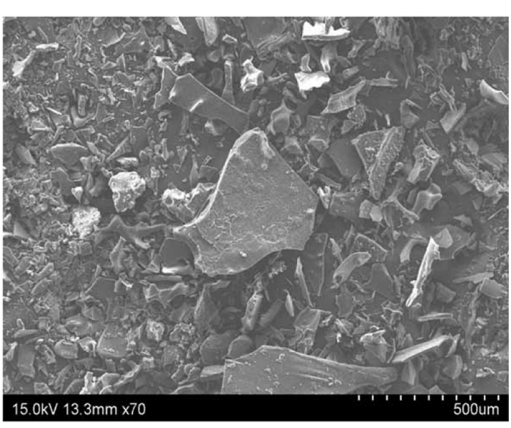

(D)

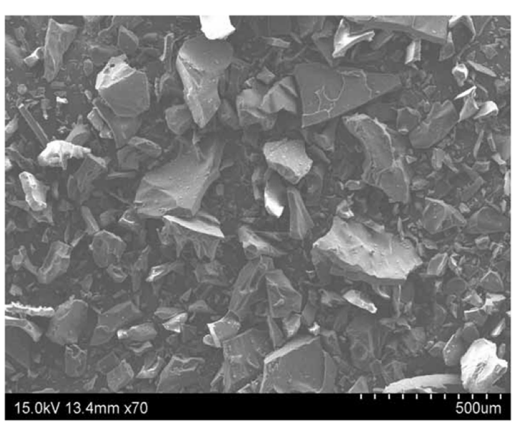

Figure 2. Scanning electron micrographs of extracts of Alnus japonica. (A), 100\% EtOH; (B), 70\% EtOH; (C), MeOH; (D), DW.

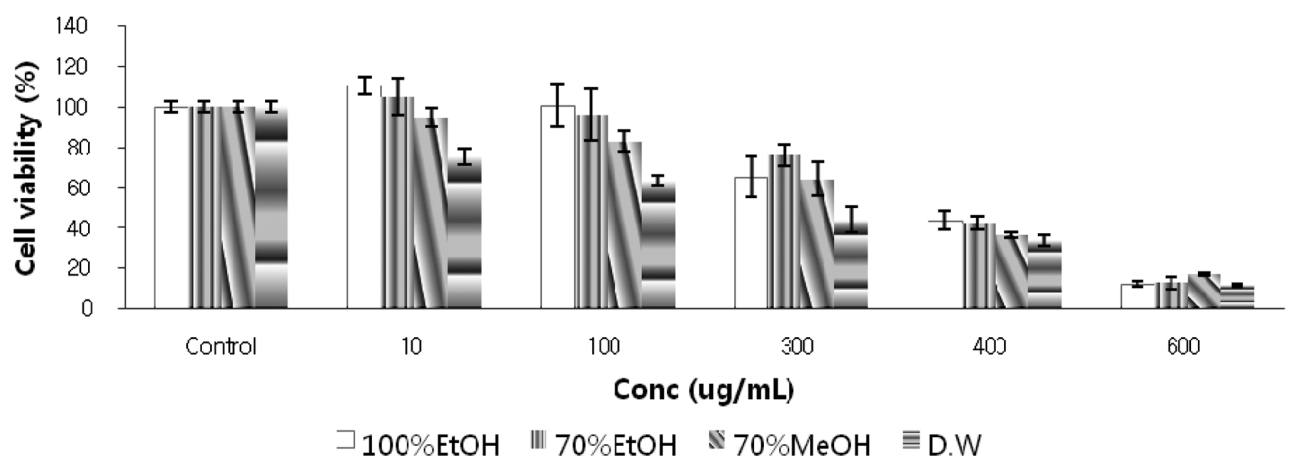

Figure 3. Cytotoxicity of four different extracts in Caco-2 cells. Each extract was applied at various concentrations on Caco-2 cells for $72 \mathrm{hr}$ before performing the MTT assay, as described in materials and methods ( $\mathrm{n}=3$; data are showed as mean \pm SD). 

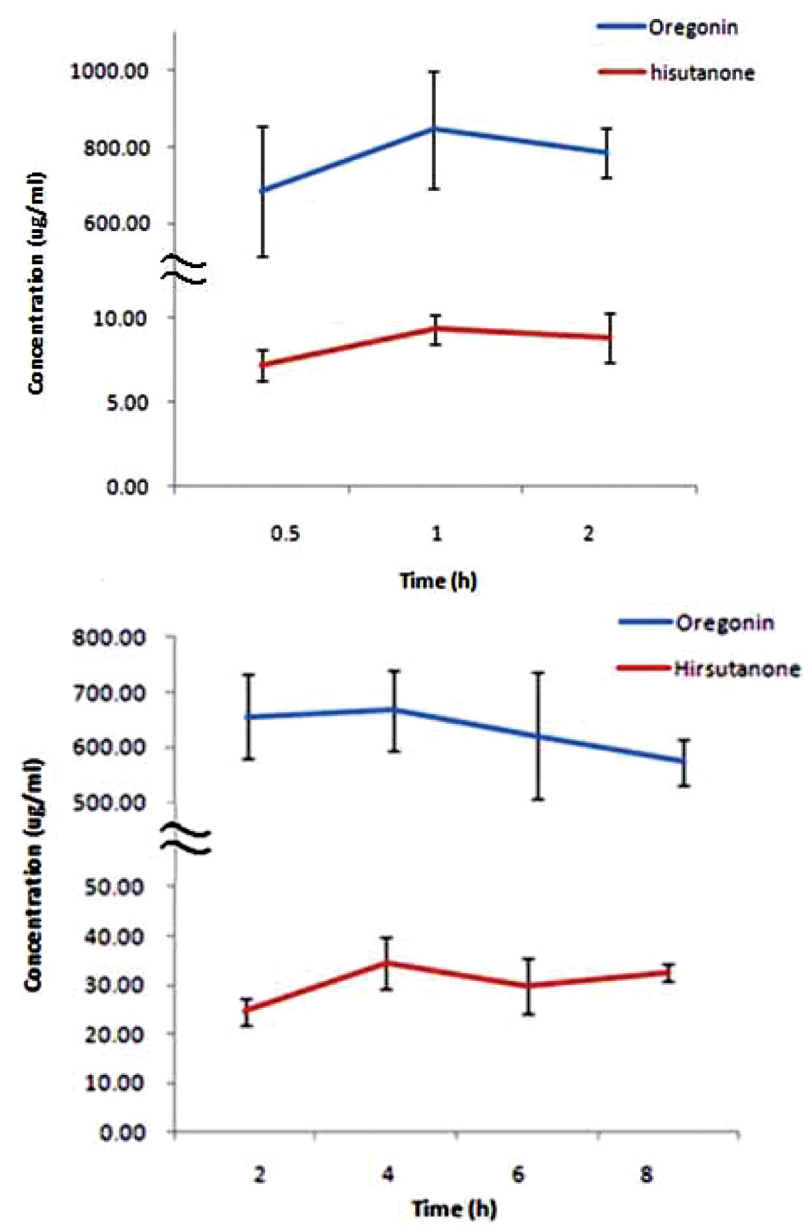

Figure 4. $\mathrm{pH}$ stability of oregonin and hirsutanone in $70 \%$ methanol extracts. (A), oregonin and hirsutanone in $\mathrm{pH} 1.2$; (B), oregonin and hirsutanone in $\mathrm{pH} 6.8$.

with water with positive surface charge would easily stick to cell membrane.

pH stability studies of $\mathbf{7 0} \%$ methanol extract obtained from Alnus japonica

On the aspect of the amount of oregonin and hirsutanone extracted from Alnus japonica using various solvents as well as cytotoxicity of extracts from Alnus japonica using various solvents, the possibilities of $70 \%$ methanol extract as herbal medicines needed to be checked. There was no significant difference in oregonin and hirsutanone from $70 \% \mathrm{MeOH}$ extracts according to the elapsed time in $\mathrm{pH}$ 1.2. As seen in $\mathrm{pH} 6.8$, oregonin and hirsutanone from $70 \% \mathrm{MeOH}$ extracts showed no significant differences. On the other hand, hirsutanone showed a higher solubility in $\mathrm{pH} 6.8$ than that in $\mathrm{pH} 1.2$, indicating more hirsutanone might be absorbed into intestinal tract than stomach. Both oregonin and hirsutanone extracted from Alnus japonica showed stability in $\mathrm{pH}$ 1.2. These results sug- gested $70 \% \mathrm{MeOH}$ extracts from Alnus japonica might be absorbed into gastrointestinal tract, systemically.

\section{Conclusions}

In this study, four different extracts obtained from Alnus japonica according to various extraction solvent were prepared and the contents of two hirsutanone and oregonin were determined. As well as, the physicochemical properties of four different extracts were characterized with scanning electron microscopy (SEM), particle size measurement, and then, cytotoxicity study of four different extracts against Caco-2 cells was carried out because of importance for development as herbal medicines. In cell cytotoxicity study, extract of water showed the highest cytotoxicity among four extracts. The extract of $70 \% \mathrm{MeOH}$ from Alnus japonica for both oregonin and hirsutanone appeared to have the highest content. Both oregonin and hirsutanone extracted from Alnus japonica using $70 \%$ methanol showed stability in $\mathrm{pH} 1.2$ and suggested $70 \%$ $\mathrm{MeOH}$ extracts from Alnus japonica might be absorbed into gastrointestinal tract, systemically.

\section{Acknowledgements}

This work was supported by the Priority Research Centers Program (2009-0093815) through the National Research Foundation of Korea (NRF) funded by the Ministry of Education, Science and Technology.

\section{References}

Lee, S.J., 1996. Korea folk medicine, Seoul National University Publishing Center Press, Seoul. 40.

Kehrer, J.P., 1993. Free radicals as mediators of tissue injury and disease. Crit. Rev. Toxicol. 23, 21-48.

Kim, J.H., Lee, K.W., Lee, M.W., Lee, H.J., Kim, S.H., 2006. Hirsutenone inhibits phorbol ester-induced upregulation of COX2 and MMP-9 in cultured human mammary epithelial cells: NF-kappaB as a potential molecular target. FEBS Lett. 580, 385-392.

Masanori K, Mari S, Yasuo N, Norio M, Takuro O, Nobuo K, Takahisa N, Toshikazu S. 2005. New diarylheptanoids from Alnus japonica and their antioxidative activity. Chem Pharm Bull 53, 1519-1523.

Choi, S.E., Jeong, M.S., Kang, M.J., Lee, D.I., Joo, S.S., Lee, C.S., Bang, H., Lee, M.K., Myung, S.C., Choi, Y.W., Lee, K.S., Seo, S.J., Lee, M.W., 2010. Effect of topical application and intraperitoneal injection of oregonin on atopic dermatitis in $\mathrm{NC} /$ Nga mice. Exp. Dermatol. 8, e37-43.

Lee, M.W., Kim, J.H., Jeong, D.W., Ahn, K.H., Toh, S.H., Surh, 
Y.J., 2000. Inhibition of cyclooxygenase-2 expression by diarylheptanoids from the bark of Alnus hirsuta var. sibirica. Biol. Pharm. Bull. 23, 517-518.

Cho, S.M., Kwon, Y.M., Lee, J.H., Yon, K.H., Lee, M.W., 2002. Melanogenesis inhibitory activities of diarylheptanoids from Alnus hirsuta Turcz in B16 mouse melanoma cell. Arch. Pharm. Res. 25, 885-888.

Kang, G., Kong, P.J., Yuh, S.V., Chun, W., Kim, S.S., 2004. Curcumin suppresses lipopolysaccharide-induced cyclooxygenase-2 expression by inhibiting activator protein 1 and nuclear factor kappab bindings in BV2 microglial cells. J. Pharmacol. Sci. 94, 325-328.

Lee, M.W., Kim, N.Y., Park, M.S., 2000. Diarylheptanoids with in vitro inducible nitric oxide synthesis ibhibitory activity from Alnus hirsuta. Planta Med. 66, 551-553.
Kim, H.J., Yeom, S.H., Kim, M.K., Shim, J.G., Paek, I.N., Lee, M.W., 2005. Nitric oxide and prostaglandin E2 synthesis ibhibitory activities of diarylheptanoids from the barks of Alnus japonica steudel. Arch. Pharm. Res. 28, 177-179.

Choi, E.J., Ko, H.H., Lee, M.W., Bang, H.W., Lee, .C.S., 2008. Inhibition of activated responses in dendritic cells exposed to lipopolysacchardie and lipoteichoic acid by diarylheptanoid oregonin. Int. Immunopharmacol. 8, 748-755.

Carstensen, J.T., 2001. Advanced Pharmaceutical Solids. New York: Marcel Dekker, 51-191.

Kuroyanagi, M., Shimomae, M., Nagashima, Y., Nuro, N., Okuda, T., Kawahara, N., Najane, T., Sano, T., 2005. New diarylheptanoids from Alnus japonica and their antioxidative activity. Chem. Pharm. Bull. 53, 1519-1523. 